\title{
UN PEACEKEEPING OPERATIONS
}

Colonel Norman L. Dodd*

\section{Introduction}

Peacekeeping operations as carried out by the United Nations today have evolved over the years since World War II and bear little relation to those envisaged by the original drafters of the Charter. In 1945 the Allies believed that the enforcement of peace could be carried out under the auspices of the Permanent Members of the Security Council. Article 42 of the Charter made provision for such enforcement operations and Article 47 of Chapter VII established a Military Committee consisting of the Chiefs of Staff or their representatives, of the five permanent members of the Council. They were charged with the planning and execution of such operations if ever required. Representatives of other nations could be invited to be associated with this Committee. These plans have only operated once, when, due to the absence of the Soviet Union from the Security Council, the UN Force was authorised to go to the assistance of South Korea (1950-53). Even then it was under US leadership and not that of the Military Staff Committee. There was also one brief period during the Congo UN operation when the UN troops were authorised to use force to maintain the cohesion of that Republic, they then took offensive action against the Katangan forces. However these operations were exceptional, and are very unlikely to take place again because of the strong opposition of some countries particularly the Soviet Union, an opposition strengthened by the two operations quoted.

It is not long before it was generally accepted that the Military Staff Committee could not carry out the tasks assigned to it. The Committee still meets once a month but the representatives of the Chiefs of Staff are of Colonel rank and nothing of substance is discussed or ever agreed. The British and French do not even maintain a permanent military representative at the $U N \mathrm{NQ}$, their representative is one of the members of their Military Attache's staff in Washington. The other three members use their permanent military officers in New York to represent them on various disarmament and similar committees so having some military influence in the United $\mathrm{Na}$ tions headquarters, the French and the British are represented on these Committees by foreign office personnel, this, some British representatives believe, is a mistaken policy because they should be able to influence UN decisions and policies which concern military affairs. Their views, which could be expressed unofficially if necessary, go by default.

\section{Articles 1 and 2 of the UN Charter}

If the United Nations was not to become completely ineffective in preventing wars, or stopping them from spreading, some other system by-passing the Military Staff Committee and the enforcement articles had to be developed. These had to conform to Articles 1 and 2 of the UN Charter; firstly that settlements of situations which are a threat to international peace and security shall be brought about by peaceful means and secondly that the UN is based upon the sovereign equality of all its members. They also had to avoid the problems which arise when the Security Council is deadlocked. What has emerged is in effect a continuation of political actions and it has become standard practice that UN peacekeeping operations are based upon two premises; one is that they may only take place with the permission of the two or more states involved and that a UN force will only be introduced into an area after a ceasefire has been agreed. Thus in effect means that no UN force will be involved in future in combat to end a dispute. By operating under these conditions the possibilities of an actual veto are reduced.

\section{Veto}

As far back as 1950 the General Assembly of the United Nations perceived that the UN might become ineffective if the veto was used consistently in the Security Council. They therefore passed a motion which became known as the 'Uniting for Peace' motion; in this they agreed that should the Security Council fail to exercise its primary responsibility for the maintenance of peace and security when there appeared to be a serious threat the Assembly shall consider the matter immediately with a view to making recommendations to members for action. The Assembly can be called into emergency session at the request of any seven members of the Security 
Council. This resolution was used at the time of the Anglo/French/Israeli conflict with Egypt in 1956 in order to place a UN force along the canal.

Even if this Resolution is invoked it is still necessary to sidestep the Military Staff Committee if any peacekeeping force is to operate; fortunately the UN Charter does provide a method. Article 98 permits the delegation to the Secretary General of 'such functions as may be entrusted to him' and Article 99 states that 'he can bring to the attention of the Security Council any matter which in his opinion may threaten the maintenance of peace and security'. These authorities granted to the Secretary General have by general consent and for want of a more acceptable solution been used to permit him to recommend the development of $\mathrm{UN}$ forces and te request contingents from member nations and to control the force once it has been deployed.

\section{The formation of a UN Force}

The basic premises under which any UN force is formed and the method of organisation in practice means that they are always 'ad hoc' formations organised at high speed during a crisis with little or no forward military planning. In fact the Secretary General today has on his staff three or four military personnel on any advisory capacity, these consist of an officer from Ghana, and one each from Ireland, Poland and Canada normally of $\mathrm{Lt} \mathrm{col}$ or major ranks. Two are on the operational side and two on logistics. Hardly an impressive military staff to help to organise a multi-national force and deploy it across the world! This lack of proper military advice and co-ordination has often caused considerable discomfort and some danger to the Un troops on the ground. The problem was realised in 1965 when the Assembly established the Un Committee on Peacekeeping, known as the Committee of 33 , charged with producing 'agreed guidelines for conducting peacekeeping operations in accordance with the Charter of the United Nations'. In spite of endless meetings nothing substantive has emerged. This is due to the fundamental difference in national views on the acceptance of any peacekeeping operations and the unwillingness of nations to commit themselves to a binding document - after all the next peacekeeping operation could be on their borders or territory!

It has therefore been left to the Secretary General and his staff, the Force Commander and the members of the UN providing contingents or personnel to evolve workable arrangements for each different operation.

UN operations fall loosely into two categories; the provision of observers and the deployment of actual military contingents. Sometimes the operations also involve the deployment of civilian police and other civilians.

\section{The Role of Observers}

Observers, generally of the rank of Captain or Major, are requested by the Secretary General from countries he considers to be 'neutral' in the dispute or interested in settling it. They are deployed to supervise cease fires, armistices and truces. After deployment the observers are placed under the control of either a Chief Military Observer or a Chief of Staff. He receives their reports from the field, where they are often sited on either side of a border or cease fire line, and after correlation, passes them to the Secretary General. These observers can and do often serve a useful and very diplomatic purpose by helping to defuse situations which might become out of hand, they act as go-betweens and can often negotiate such matters as traditional grazing rights. UN observers have been helping to keep the peace in divided Kashmir since 1949 and are still there today. An observer group was deployed to the Yemen in 1963/64 but its terms of reference were unsatisfactory and it was unable to carry out any effective work. Others were more successful on the Indian/Pakistan border in 1965/66 and the UN Truce Supervision Organisation (UNTSO) with its headquarters in Jerusalem has and is doing useful work in the Sinai. This observer force is somewhat unique because it contains 36 US and the same number of Soviet officers, normally neither of these countries is asked to provide troops for UN forces. Another observer group, the UN Disengagement Observer Force, (UNDOF) is presently deployed on the Golan Heights between Israel and Syria.

\section{The UN Peacekeeping Forces}

It is the UN Peacekeeping Forces which are more normally in the public eye. It is being realised by a number of smaller countries that by sending contingents to these forces they can obtain a place on the world stage which they would not normally have by reason of their size and economic influence. Fiji, Nepal and Ghana are amongst the countries participating in the UN Interim Force in Lebanon (UNIFIL) at the present time. It costs very little to provide forces 
because the UN meets almost all the expenses paying about 950 US dollars per month for each officer and man deployed plus 280 dollars extra for certain specified specialists. A surprising number of countries have, over the years, provided troops, more than 22 did so in Korea, the UN Emergency Force II in the Middle East, now withdrawn, had contingents from 16 countries, 35 countries supplied contingents or personnel to the Congo operation and presently there are infantry battalions from Fiji, Ghana, Ireland, Nepal, the Netherlands, Nigeria, Norway and Senegal in UNIFIL plus logistic units from France, Italy, Norway and Sweden, a total of about 6000 officers and men. The Commander is presently Lt gen William Callighan of Ireland.

\section{The Mandate}

The effectiveness of any UN Force depends upon the Mandate it is given by the Security Council and the competence of the Commander and his men. For political reasons the Mandate is normally only given in the widest terms otherwise no agreement to its establishment would ever be reached. It would be naive to believe otherwise. However the very vagueness has its advantages for it permits the Secretary General and the Commander of the Force to act pragmatically to each situation and to deal with all parties to a dispute without any suggestion that they are being formally recognised by the UN. It further permits considerable flexibility of operation within the wide Mandate; the parties to the dispute can also make use of this flexibility of interpretation but this is outweighed by the value to the Secretary General and to the Force Commander. Over the years the Secretary General and his staff have developed considerable skill in the day to day direction of the UN Forces; the confidence which this has generated has become apparent in the way in which his direction is now widely accepted by the Security Council - who are very adverse to changing any Mandate after it had been approved even if the circumstances change.

\section{The Selecting of the Commander}

The Commander of the Force is selected by the Secretary General and it is customary that he makes certain the person selected is acceptable to the parties to the dispute. He must be of broad competence as a military man yet have a full understanding of the political problems underlying the dispute. He must be 'neutral' at all times and has to bear in mind that the Force is there for peacekeeping and not for military enforcement. Military force is only permitted in the last extreme, if UN troops are actually attacked, they may then defend themselves using minimum force. Decisions in such cases are easy but more difficult situations can occur when the Commander may think that his troops are being prevented by force from carrying out their Mandate. Such a situation arose in Cyprus after the establishment fo the UNFICYP in 1974; this problem followed the invasion of Cyprus by Turkey so creating a situation which was not envisaged when the Force's Mandate had been agreed ten years earlier. The Secretary General ordered the Force Commander of UNFICYP to make every effort to maintain the ceasefire 'while continuing to act within the spirit of the present mandate.' It became immediately apparent that if the Force was to do this it would have to prevent the Greek Cypriots and the Turks and their Turkish Cypriot allies from fighting to gain physical possession of the Nicosia Airport at the time precariously held by the Greek Cypriots. The Force Commander, the experienced General Prem Chand, took a risky and unilateral decision to order the UN Forces to occupy the airport and to deny it to both sides. His action could be termed to be correct under the old Mandate and it was approved by the Secretary General. It was a bold action because only limited UN Forces were available and the Turkish authorities challenged the operation. However the timely arrival of UN re-inforcements in the form of British armoured cars from the British Base and of some RAF Phantoms plus vigorous political and diplomatic pressures prevented actual combat taking place and saved a very dangerous situation. The success was due to the strength of character of the Commander and the courage of the troops on the ground who had to insert themselves between the contestants with very little 'muscle' if things went wrong.

Such courage has been shown many times by UN Forces; one of the most outstanding efforts was that of a small Finnish detachment which took place at Suez in October 1973 at the time of the Yom Kippur War. The Security Council decided at very short notice to insert a UN force, the UNEF 2, between the opposing Egyptian and Israeli troops immediately after a ceasefire had been agreed. Within 48 hours of this decision troops from three contingents were flown from UNICYP to Cairo and rushed to the area. A small detachment of Finns moved straight to the Canal 


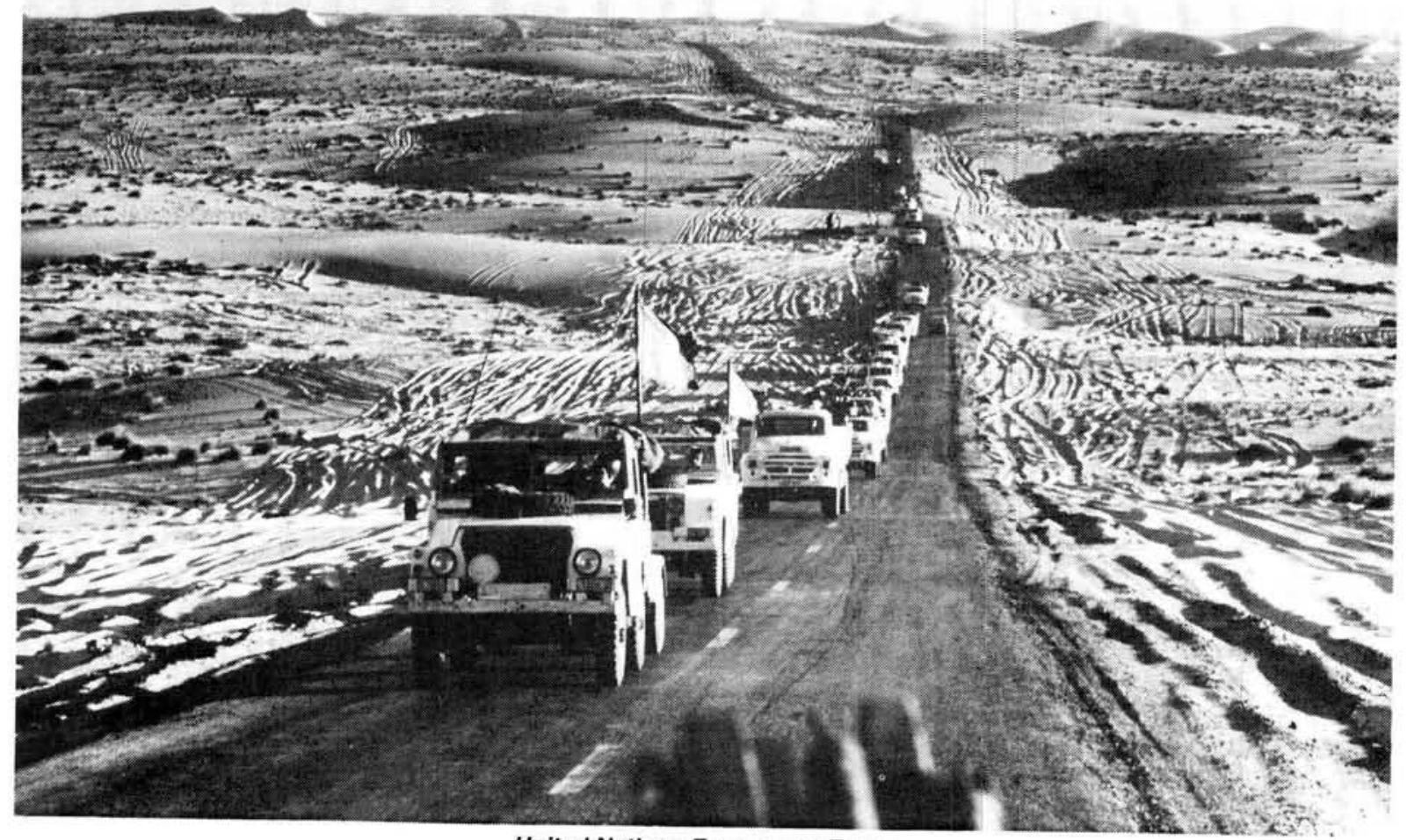

United Nations Emergency Force Israel occupied Sinal, Egypt, 9 Nov 1973

Photo: United Nations / Y. Nagata
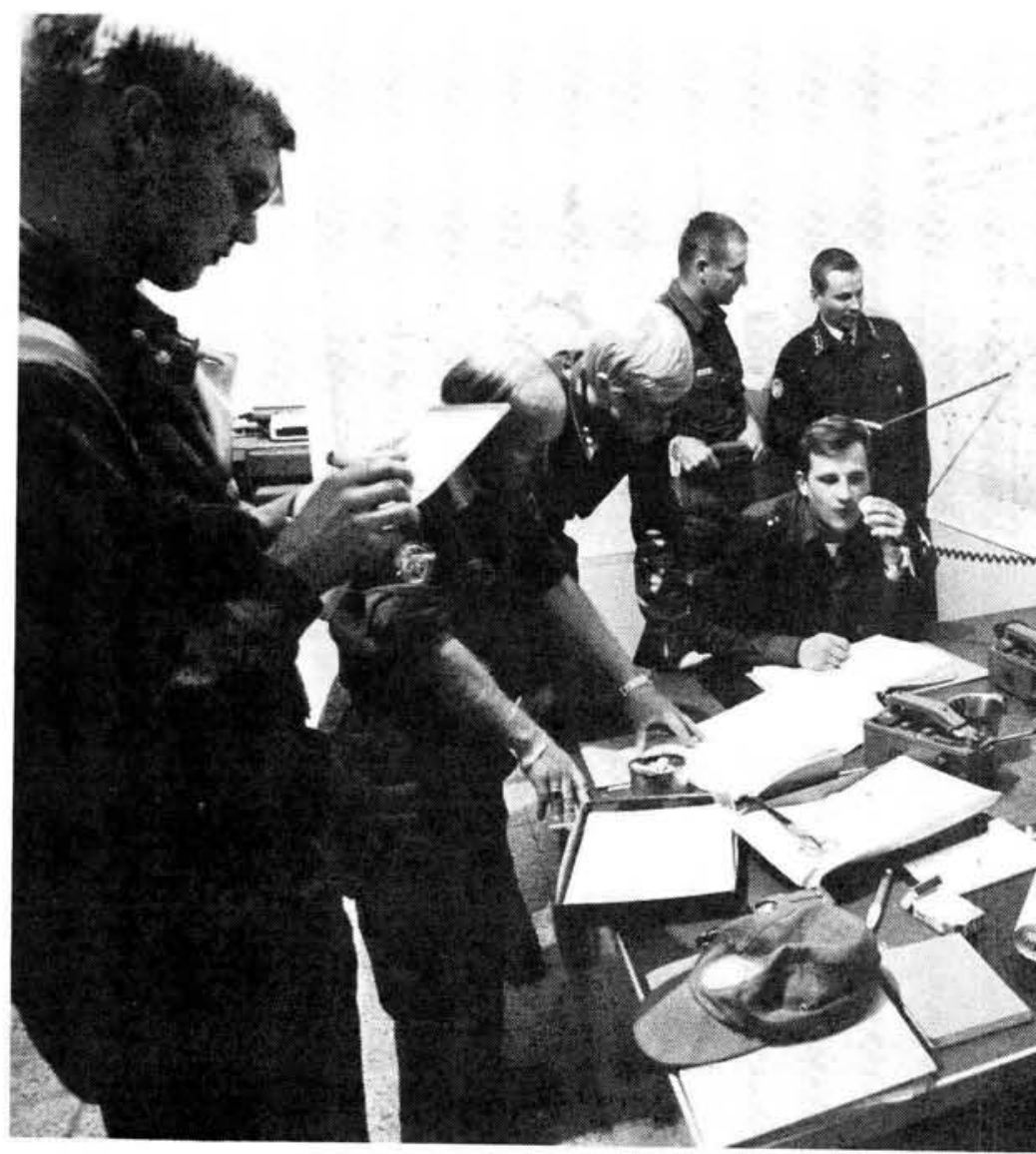


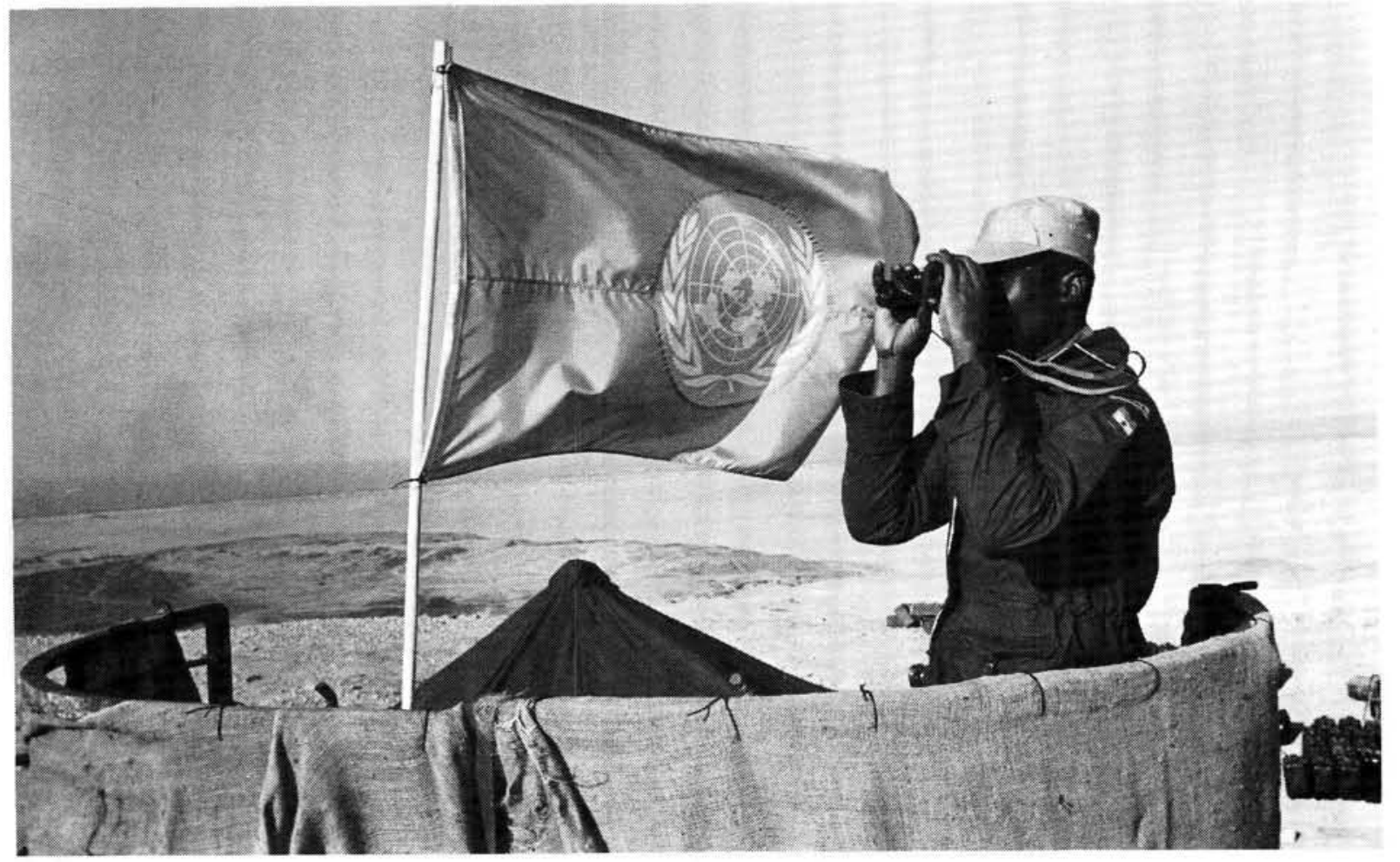

United Nations Emergency Force
Gabel Gineifa, Egypt, 3 Feb 1974

Pabel Gineifa, Enited Nations / Y. Nagata

and actually interposed themselves between the still very 'trigger happy' contestants. They did so, as other have done before and since, with little else besides their courage and UN Blue Berets to protect them.

Much of the success which the UN peacekeeping operations have had has been due to the courage and effectiveness of the troops on the ground and insufficient credit has been given to them. Their failures have always been due to their being given impossible mandates. Some countries believe that any well disciplined and trained troops can be employed on UN peacekeeping duties and to some extent this is true because discipline, initiative and courage are required attributes of all soldiers. However the conditions under which US soldiers are called upon to serve are very different from those for combat soldiers are trained. Soldiers are taught to be offensive, to fight to win, to kill or render ineffective, specified and identifyable enemies and to use the maximum fire power, artillery, armour and aircraft to obtain their objectives. This is not so in UN peacekeeping. There are no enemies, everyone must be treated equally and none can be considered as allies or enemies; UN soldiers are armed only with small arms and have orders not to use them except in the last resort to defend themselves from direct attack.
The UN soldier does not attack to capture objectives and normally does not hold ground although at times he must stand firm and refuse to be removed from his observation post. He must never lose his temper or become over aggressive, he must gain his point by diplomacy and by firmness of discussion and decision.

\section{The Reservist}

Some members of the staff of the UN believe that it is often the reservist, the conscript who has had some experience in civilian life and the men who, as in the Nordic countries, volunteer for short periods for service with UN contingents who make the best peacekeepers. These categories of soldiers can and do identify well with the people they are protecting, their civilian skills and professions often make them more acceptable than the younger regular soldiers to the civilian population in the area in which they operate. UN sodiers often have to deal with the local civilians rather than the the military forces of the contestants.

However regular officers and soldiers have much to offer; they are trained and skilled in planning operations, in organising movements and making logistic arrangements and their already mentioned attributes of discipline, cou- 
rage and steadfastness. These make them a valuable asset in any Force. The technically trained engineers, signallers, drivers, mechanics, butchers, cooks and other military trademen, not to mention professional doctors and dentists, nurses and orderlies, are all required by any Force and often it is from the regular forces that these personnel must be found.

The Nordic countries of Norway, Sweden, Denmark and Finland have always been enthusiastic supporters of the UN peacekeeping concept. Together they have about 5,000 troops either on UN service or on standby. Special staff college courses on peacekeeping have been established and the officers and men undergo specialised training. The Netherlands also have a trained peacekeeping battalion made up of volunteers from their conscript army. Because there is no agreed UN handbook or staff instruction on the organisation and standing operational procedures of Un peacekeeping forces the International Peace Academy located in New York has filled the gap. This seat of learning is staffed by retired officers who have considerable experience in peacekeeping operations and the Academy is devoted to studying, improving and propagating knowledge on this subject by means of courses, papers and symposiums. The manual they have produced is edited by Brigadier Michael Harbottle, once Chief of Staff of the INFICYP, and is called 'The Peacekeeper's Handbook'. It is a systematic guide and covers problems from communications, reports, orders, planning, logistics to training requirements. It is a very practical handbook and has, at least, unofficially, been adopted by many nations providing, or intending to provide, contingents or individuals to the UN Forces.

Over the years a great deal of expertise has been built up at the UN HQ and in a number of countries the arts of peacekeeping under the somewhat difficult Mandates of the UN. In spite of the handicaps of the lack of proper staffs at the UN HQ forces are assembled and despatched very rapidly and, sometimes involving discomfort and danger of the troops involved, they have in general been reasonably successful. Unfortunately the diplomatic efforts which accompany, and follow, the arrival of the forces have been less successful in settling the disputes. Only too often as in Kashmir and Cyprus and possibly in the Lebanon today, the UN intervention has 'frozen' the situation rather than settled the problem. This has not been from want of trying; the necessity for parallel political action is recognised by the appointment of a Political and Legal Adviser and small staff to assist the Force Commander in the field. In some cases, Cyprus is an example, there is a Special Representative of the Secretary General, he has equal status to the Commander and is responsible for settling local disputes and for attempting to develop a situation in which tension is decreased so permitting a long term solution to be negotiated. The long term solutions are far harder to obtain because of basic differences and antagonisms between the parties to the disputes.

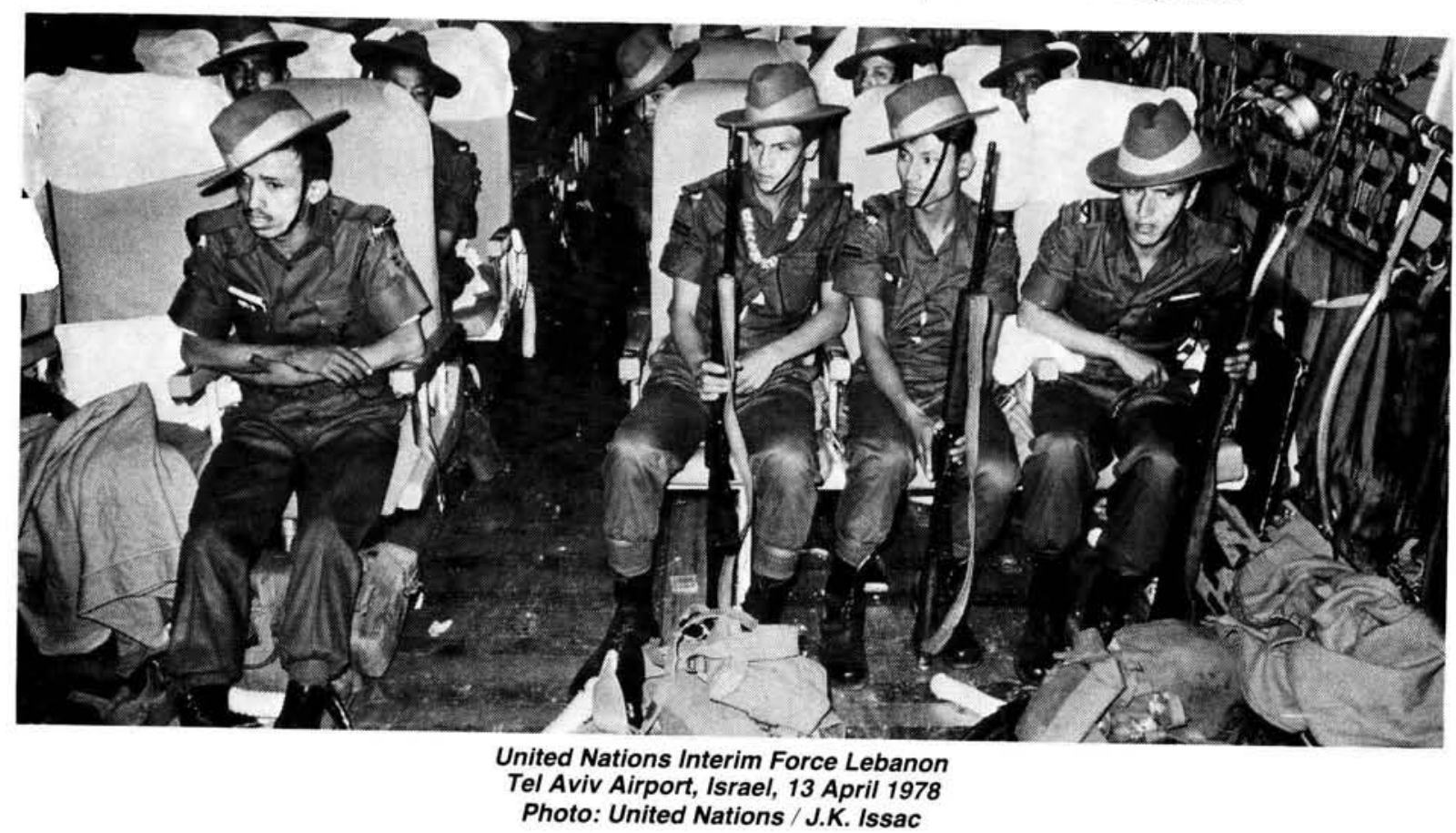




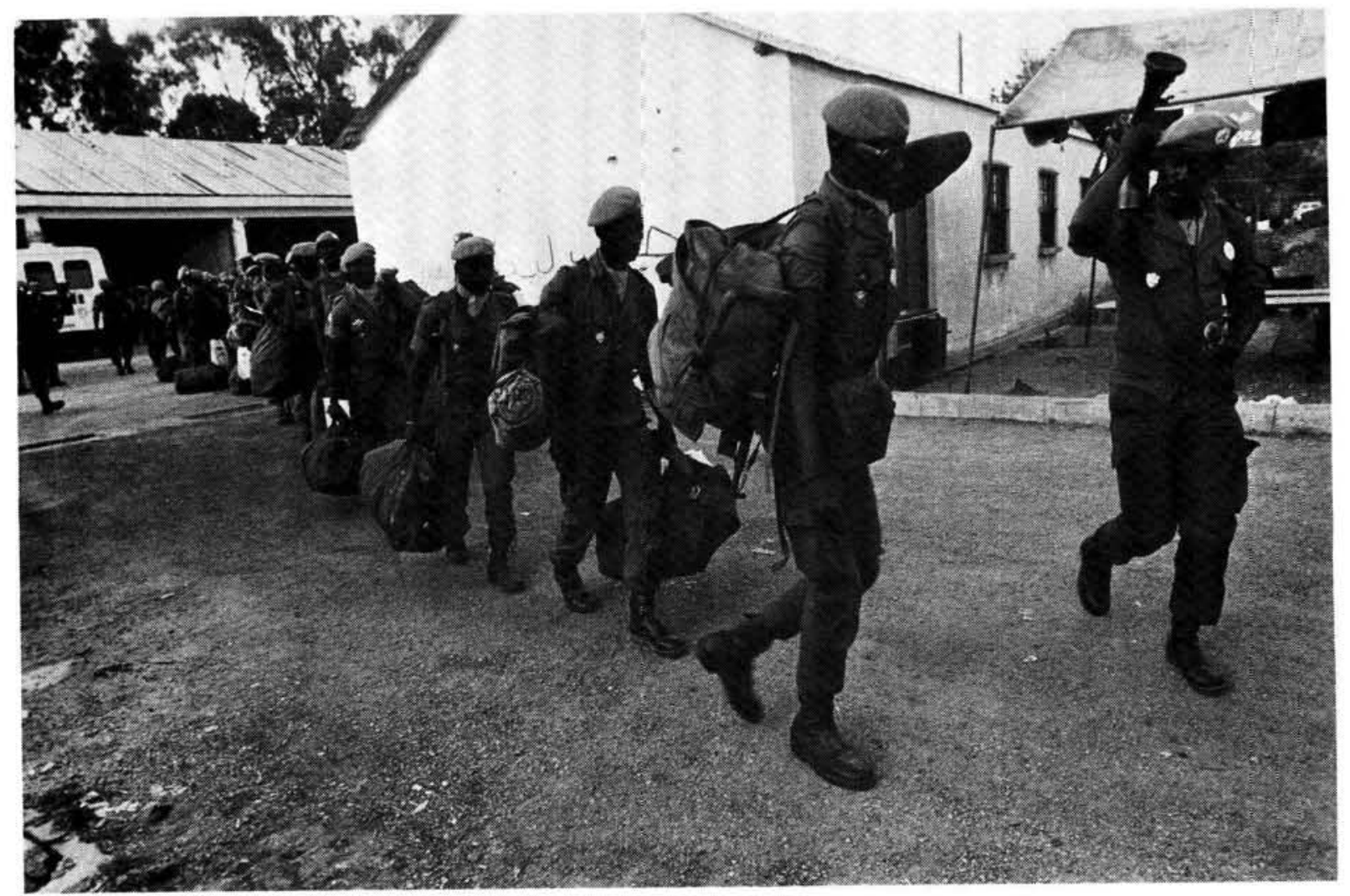

United Nations Interim Force In Lebanon

Tyre, Lebanon, 27 April 1978

Photo: United Nations / J.K. Issac

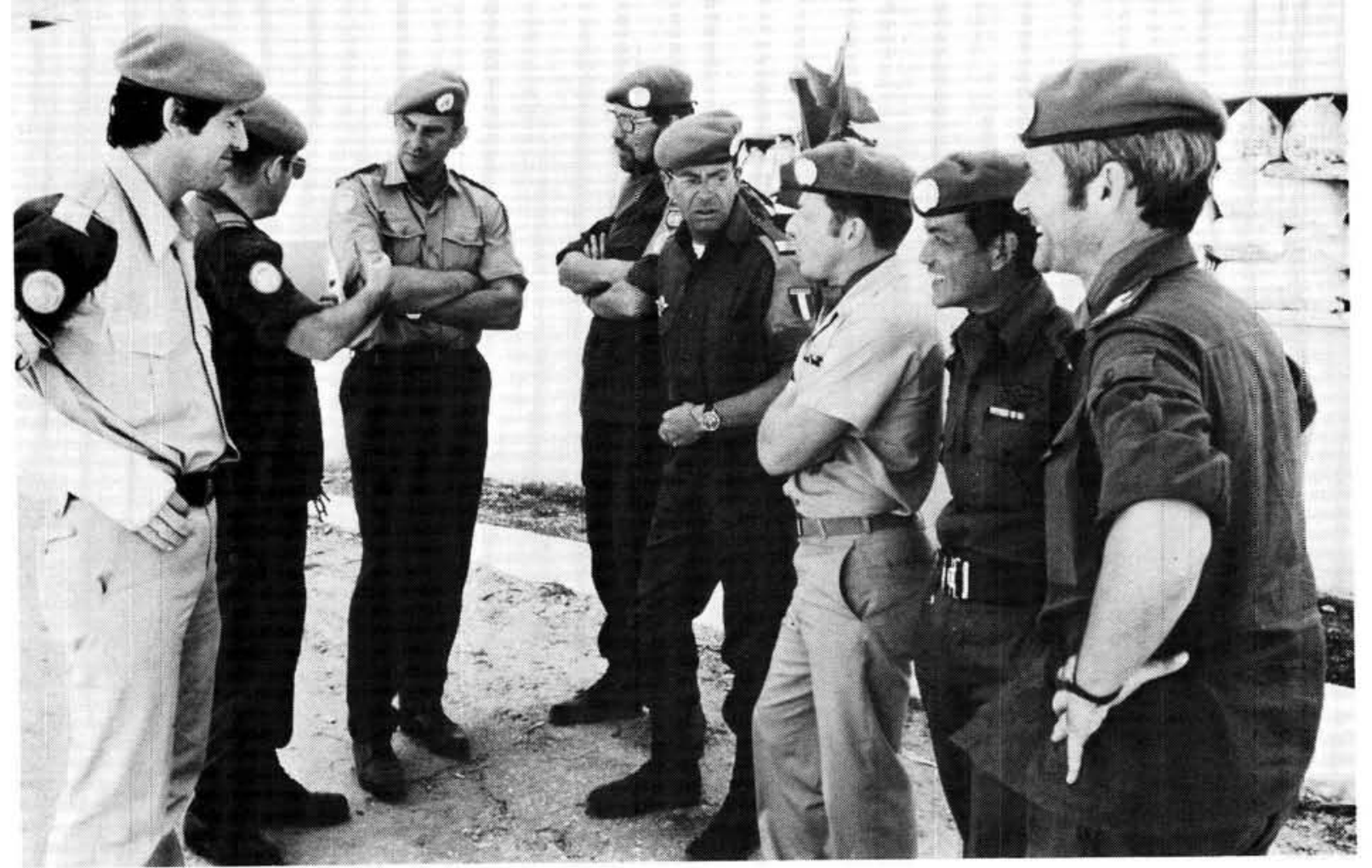

United Nations Interim Force In Lebanon

Naqoura, Lebanon, 29 April 1978

Photo: United Nations / J.K. Issac 


\section{Problems}

One of the problems which the UN has faced over peacekeeping operations is that of 'who should pay for them'? The matter was referred to the International Court of Justice, the Court gave an advisory opinion that the expenses incurred are a charge on the Organisation as a whole. However this ruling is somewhat academic because nobody can force a powerful member of the UN, or one of its Allies, to pay if they do not agree to do so. A special scale of assessments was made by the staff of the UN; for Middle East operations this is $63 \%$ for the Permanent Members of the Security Council, other developed nations $35 \%$, and for the smaller nations $2 \%$. However some members refused to pay anything and the Soviet Union paid half their assessment. The USSR maintains that only the Security Council can authorise, maintain and finance the operations and so will only finance those with which she positively agrees; France holds the view that peacekeeping operations are voluntary and so will only help to pay for those in which she participates. China claims that these operations are contrary to the Charter of the UN because they interfere in the internal affairs of member nations although she has not yet actually vetoed the UN operation. To avoid having a proposed UN Force vetoed and so cause a complete upheaval it is usual for the Secretary General to first insure by discussion that his proposal will go through. Because of a certain veto by the USSR the proposal to extend the Mandate of UNEF II in the Sinai to monitor the withdrawel of the Israeli forces agreed at Camp David between Egypt and Israel was quietly dropped and the Force was disbanded. In its place a non-UN multi-nation force acceptable to Egypt and Israel has been formed by the United States; this is likely to consist of one third US troops and two thirds from other countries these include the UK, France and Italy and the US has announced that Fiji will provide a contingent.

\section{Room for improvement}

Although the Secretary General's department have shown considerable skill in the formation and control of UN peacekeeping forces there is much room for improvement. Hopefully the Military Staff Committee could be reformed to give it some capability to improve military planning arrangements but this may still be politically impossible. However a senior military adviser could be appointed to help the Secretary General in order to attempt to avoid 'military nonsenses' in the future. The UN Civilian Field Service Division, which is charged with assisting the Secretary General in the planning and implementation of all logistic and administrative support of UN operations, should be augmented by some experienced logistic service officers. More co-ordination of planning could take place at world regional level even if it is not possible to do this at the UN itself; such co-operation is permitted under Article 52 of the UN Charter. The European, Latin American and Asian members could follow the lead of the Nordic countries and set up regional forces and procedures. Australia could well take the lead in the Asian region. Britain could do so in the European Economic Community and Brazil in Latin America.

Stockpiles of equipment should be provided to enhance the capabilities of the smaller nations, at present the UN has some depots but stocks are poor, these stockpiles could have a secondary purpose in that they could be used for assistance after natural disasters. Of necessity UN Peacekeeping forces have to be conspicious; the present Blue Berets, UN Flags and white markings on vehicles are insufficient; clearer markings and perhaps a special over uniform are required to ensure that members of the contingents are instantly recognised.

The effectiveness of the whole of the UN operations would be greatly enhanced if some of the larger nations, but not the Great Powers of US and USSR, would take a more active part in them. France and Great Britain have assisted, the former in the Lebanon and the latter in Cyprus but elsewhere only in a low key, they should be much more active in their support. Japan and West Germany, for historical reasons, have played virtually no part in these operations, they are wealthy countries and could well afford to do so, they could raise special forces for the UN and provide much needed back-up support. Australia, New Zealand, Malaysia, Spain, and the Argentine and Mexico are other nations who could play a much more prominent part in supporting UN operations. The opportunity for these, and other nations, to play a more prominent part in peacekeeping and so in the affairs of the world in general may well be presented if and when agreement is reached for a 'ceasefire' on the Namibian/Angolan border and the subsequent UN supervised elections. Contingents and observers will be required for UNTAG, the Force proposed for the area. The long drawn out discussions on this problem have permitted a lead 
time for preparations; the area is difficult and proper military planning for the insertion of a Force into an area is essential. The writer understands that the UK and Australia are amongst the Nations who may agree to participate, if this is so their military planners should aiready be holding meetings with the UN staff and their military representatives visiting such UN Forces and UNIFIL to gain experience and learn from those already involved.

To a military man the launching of an operation requiring the participation of a number of divergent nations without proper previous planning is against all his instincts yet, perhaps because of the short notice and of the basic training of military staffs, the contingents have been able to arrive without any actual losses and have subsequently carried out their duties. However this should not obscure as it sometimes does in civilian government and United Nations circles, that considerable discomfort to the troops could have been avoided by proper planning. The Governments of member nations have an obligation to their Armed Services that they should make every attempt to improve procedures for the planning and launching of peacekeeping operations and for the proper training and support of their contingents. In a turbulent world these operations will also have a role to play.

\begin{abstract}
Bibliography
* Col Norman L. Dodd was commisioned into the Royal Artillery in January 1937. After having served in many parts of the world inter alia as Senior British Liaison Officer to the US Army and Central Army Groups in Europe, and Chief of Public Relations for Allied Command Central Europe, he, retired in 1970 to become Defence Correspondent. Col Dodd's articles are published regularly in military and other magazines in many parts of the world. He is the British Defence Correspondent for Pacific Defence Reporter, Asian Defence Journal, Detensa. Armed Forces Magazine, Wehrkunde and other magazines providing tri-service articles on many subjects and reports on new equipment, exhibitions and demonstrations attended on behalf of the magazines.

Col and Mrs Dodd live in Sidmouth on the Devon coast in England.
\end{abstract}

